\title{
Students' Mobility and the Impact on the Administration of Secondary Schools in Nigeria
}

\author{
Prof. Victor F. Peretomode \& Dr. (Mrs) Ogheneruona E. Iggue \\ Professor of Educational Administration \& Higher Education, Department of Educational Administration \& \\ Policy Studies, Delta State University, Abraka, Nigeria. \\ Teaches at the Ogbuiwangwa Secondary School, Warri, Delta State, Nigeria.
}

\begin{abstract}
The paper examines the rate, trend, gender, location and the causes of secondary school students' inter-school mobility in Delta State of Nigeria. It also determines the problems associated with school administrative tasks as a consequence of this phenomenon.

An instrument titled, Students' Inter-school Mobility and School Administration Questionnaire (SISMABAQ) was developed and subjected to validity with a test retest reliability coefficient of 0.78 . This instrument was used to solicit responses from a sample of 399 school administrators. The sample was selected from a population of 1113 school administrators based on stratified random sampling technique. Descriptive statistics-frequency, percentage and the mean - were used to analyze the data. The findings show that the rate of movement was low, higher in rural areas than in urban areas, but on the whole was fairly steady. Several factors were identified as reasons for the phenomenon with the top-most being examination malpractice, indicating that most students moved because they wanted to make good grades in their High School Certificate Examinations but without working hard to earn those fine grades. On the whole, the phenomenon of student mobility negatively affected secondary school administration in Delta State of Nigeria.
\end{abstract}

Key Terms: Academic performance, administrative tasks, drop-out, inter-school movement, inter-school transfer, secondary school administration, student mobility.

\section{Introduction:}

Education is recognized as an indispensable powerful instrument for the socio-economic, political, scientific and technological transformation of nations. It is a precursor for change and innovations and it provides the individual with the necessary ideas, values, attributes, attitudes, behaviour, knowledge and skills that enable him or her to live as a useful, efficient and effective member of his/her society.

Formal education, in most cases is classified into primary or basic, secondary and tertiary education. Secondary education is that which children receive after primary education and transit to the tertiary stage. It therefore occupies a central position in all nations' educational system (National policy Education (NPE), $4^{\text {th }}$ Edition 2004). It equips youth with certain fundamental skills for employment and as a basis for proceeding to tertiary institutions of learning depending on ability, interest and capacity.

In recent times, there have been indications that secondary schools have experienced and continue to experience an increase in students' inter-school mobility, a practice wherein students change schools, leave one school for another other than when they are promoted from one school level, such as when students are promoted from primary school to Junior secondary school (JSS) or JSS to senior secondary (SSS). This phenomenon is quite different from what is referred to as inter school transfer. In the latter, the "moving student was accepted when the receiving school is satisfied not only with the academic performance of the student who is moving" but also gets a good transfer certificate from the Head teacher of the student's previous school. But in the former, that is inter-school mobility, such movements from one school to another do not require these essential transfer reports. Mobile students can change in between school years, such as during the term, or during the school year (http// educstate university.com, 2013).

Student mobility is a worldwide phenomenon because people must move. In Nigeria, there are no recognized statutory rules or regulations or policies per say to guide the process of inter-school mobility in the educational system. From observations, this phenomenon has been given much encouragement because the criteria for transfer and acceptance into schools are locally determined by each school head since all post primary schools, whether public or private, are to a large extent similar in structure and curriculum offering.

\section{Statement of problem}

Inter-school mobility appears to be a recent phenomenon in Nigeria, becoming more evident in the late 1980 's and early 1990's. Prior to this period, the country had inter-school transfer and movement was generally limited to a specific period of time and stage of study. Inter-school mobility on the other hand, is characterized by indiscriminate movement of students from one school to another at the same level and even at a higher level 
not qualified for. Outside Nigeria, there has been a number of separate studies on inter-school mobility (Bilquees \& Saqib, 2004), Schwartz, Stiefel \& Chalico (2007), Smither and Clarke (2008), Hanushek, Kain \& Rivkin, 2004) and Rumberger (2003). These authors used several terms to refer to the same phenomenon "minority movement," minority enrollment", "geographic mobility," "academic mobility", switching schools," student mobility, inter-school movement etc.

The school is an open system. It requires certain inputs as well as checks and balances to carry out curriculum activities so as to achieve the desired goals and objectives. The school system in Nigeria entertains a lot of movement of students, a situation which principals, teachers and parents appear to have taken for granted as the phenomenon takes place through out the school session. The situation seems not to have attracted much attention on the part of educational authorities and so not much studies have been conducted to determine the impact of this phenomenon on secondary school administration in the thirty six states of the country. One of such early studies in Nigeria is that conducted by Ofuegbu (1996) as part of her doctoral thesis in the University of Benin, Benin-City, Edo State. It is against this backdrop that this study is being conducted raising similar research questions but using a different State in Nigeria. Ofuegbu study was carried out in Edo State more than a decade and half ago.

\section{Purpose of the study:}

The purpose of the study therefore, was to determine the rate, trend and factors responsible for students' mobility and the problems associated with such phenomenon in the administration of secondary schools in Delta state.

\section{Research Questions}

Specifically, four research questions were raised to guide the study as follows;

1. What is the rate of students' inter-school mobility, and by location, in the state?

2. What is the trend of this phenomenon?

3. What factors contributed to this phenomenon?

4. What are the consequences of students' mobility on the administrative tasks of heads of secondary schools in the state?

\section{Methodology}

The study adopted the ex-post-facto research design because both independent variables (factors causing student mobility) and the dependent variable (the impact on administrative tasks) had already occurred and the researcher is only looking backwards to determine if the independent variables had influence on the dependent variable (school administration).

The population of the study was 1113, comprising 371 principals and 742 vice-principals in Delta State public post primary schools distributed across in the three senatorial districts of the state. The sample size of 133 principals and 266 vice-principals was selected based on stratified random sampling technique.

A research instrument titled 'Students' inter-School mobility and School Administration Questionnaire" (SISMASAQ) was developed, validated and tested for test-retest reliability and used to collect data for the study. The reliability coefficient for the dimensions of school mobility was 0.83 and that of administrative problems was 0.89 . The Cronback alpha scale for interval consistency of the items was 0.74 .

The three hundred and ninety-nine (399) questionnaires were personally administered, with the aid of a trained assistant, on the respondents in 133 randomly selected secondary schools located in the three senatorial districts of the state over a two months duration. Simple descriptive statistics were used to analyze the data.

\section{Results and Discussion}

The results obtained have been presented according to the research questions raised to guide the study.

Research Question 1: The rate of student's inter-school mobility, and by location.

In order to answer the research question, the data was analyzed using percentage. The result of the analysis is presented in Table 1.

Table 1

Analysis of the rate of Students' Inter -School Mobility in the Sampled Secondary Schools.

\begin{tabular}{|c|c|c|c|c|}
\hline ACADEMIC SESSIONS & $\begin{array}{c}\text { NO. OF } \\
\text { SCHOOLS }\end{array}$ & $\begin{array}{c}\text { TOTAL ENROLMENT } \\
\text { FIGURE }\end{array}$ & $\begin{array}{c}\text { TOTAL STUDENT } \\
\text { MOBILITY }\end{array}$ & $\begin{array}{c}\text { MOBILITY RATE } \\
\text { (\% SCORE) }\end{array}$ \\
\hline $2005-2006$ & 133 & 104,815 & 5979 & 5925 \\
\hline $2006-2007$ & 133 & 83,699 & 5439 & 7.08 \\
\hline $2007-2008$ & 133 & 97,602 & 5410 & 5.57 \\
\hline $2008-2009$ & 133 & 65,018 & 5.32 & 6.05 \\
\hline $2009-2010$ & 133 & 94,863 & $\mathbf{2 8 , 4 9 5}$ & $\mathbf{6 . 5 4}$ \\
\hline TOTAL & & $\mathbf{4 4 5 , 9 9 7}$ & & \\
\hline
\end{tabular}


Table 1 shows that the total enrollment for the period (2005-2006-2009-2010 session) was 445,997 while the total number of students who engaged in inter-school mobility was 28,495 . The table also indicated that the overall rate of students' inter-school movement for the period under study was $6.54 \%$. The table, however, indicated that the least rate of 5.57\% was recorded during the 2007/2008 session while the highest rate of $8.32 \%$ was recorded during the 2008/2009 academic session.

The students' mobility was further analyzed according to year and location of school (rural and urban). The number of secondary school students that were involved in inter-school mobility from the sampled schools according to location over the period of study as well as movement rates were calculated and presented in Table 2.

Table 2

Analysis of Movement according to Year and Location

\begin{tabular}{|c|c|c|c|c|c|c|}
\hline $\begin{array}{l}\text { ACADEMIC } \\
\text { SESSIONS }\end{array}$ & \multicolumn{2}{|c|}{ ENROLMENT FIGURES } & \multicolumn{2}{|c|}{ MOVEMENT FIGURES } & \multicolumn{2}{|c|}{$\begin{array}{l}\text { MOVEMENT RATE (\% } \\
\text { SCORE) }\end{array}$} \\
\hline \multirow{4}{*}{$\begin{array}{l}2005-2006 \\
2006-2007 \\
2007-2008 \\
2008-2009 \\
2009-2010\end{array}$} & $\begin{array}{c}\text { URBAN } \\
\mathrm{N}=70\end{array}$ & $\begin{array}{c}\text { RURAL } \\
\mathrm{N}=63\end{array}$ & URBAN N=70 & RURAL N=63 & URBAN N=70 & RURAL N=63 \\
\hline & 52,627 & 31,072 & 31,072 & 2,063 & 7.34 & 6.64 \\
\hline & 70,069 & 27,555 & 3,481 & 1,958 & 5.00 & 7.10 \\
\hline & 43,329 & 21,689 & 3,513 & 1,897 & 8.10 & 8.75 \\
\hline TOTAL & 307,661 & 138,328 & 18,397 & 10,098 & 6.00 & 7.30 \\
\hline
\end{tabular}

Table 2 showed the relative rate of students' mobility among secondary school students in urban and rural areas. The data indicated that the over-all enrollment figure for urban areas was 307,661 while that for rural areas was 138,328 . The data further indicated that the total student movement recorded for urban schools was 18,397 while the total student movement for rural areas was 10,098. The calculated overall movement rate for urban areas was $6 \%$, while that for rural areas was $7.30 \%$. The result also showed that the rate of inter-school movement was consistently higher in rural than urban areas except for the 2006/2007 session. This was evident when the relative rates of students' movement in urban and rural areas were compared for each of the sessions as shown in Table 3.

Table 3

Relative rates of Students' Inter-School Movement between rural and urban areas in percentages.

\begin{tabular}{|c|l|c|c|c|c|c|}
\hline \multicolumn{2}{|c|}{ ACADEMIC SESSION } & $\mathbf{2 0 0 5 / 2 0 0 6}$ & $\mathbf{2 0 0 6 / 2 0 0 7}$ & $\mathbf{2 0 0 7 / 2 0 0 8}$ & $\mathbf{2 0 0 8 / 2 0 0 9}$ & $\mathbf{2 0 0 9 / 2 0 1 0}$ \\
\hline \multirow{2}{*}{ LOCATION } & RURAL & 6.70 & 6.04 & 7.10 & 8.75 & 7.82 \\
\cline { 2 - 7 } & URBAN & 5.25 & 7.34 & 5.00 & 8.10 & 5.40 \\
\hline
\end{tabular}

\section{Research Question II}

What is the trend of students' Inter-School Mobility?

To find out the trend of movement, the mobility figures were subjected to statistical analysis using the percentage score. The result of the analysis is presented in Table 4.

\section{Table 4}

Trend of Students' Inter-School Movement

$(2005 / 2006-2009 / 2010)$

\begin{tabular}{|c|c|c|c|}
\hline ACADEMIC SESSIONS & ENROLMENT FIGURES & MOVEMENT FIGURES & $\begin{array}{l}\text { OVERALL RATE PER } \\
\text { SESSION (\% SCORE) }\end{array}$ \\
\hline $2005-2006$ & 104,315 & 5979 & 5.71 \\
\hline $2006-2007$ & 83,699 & 5925 & 7.08 \\
\hline $2007-2008$ & 97,602 & 5439 & 5.57 \\
\hline $2008-2009$ & 65,018 & 5410 & 8.32 \\
\hline $2009-2010$ & 94,863 & 5742 & 6.05 \\
\hline
\end{tabular}

Table 4 shows that for each of the sessions studied, a total of 5979,5925,5439,5410 and 5742 students moved into all the schools for each session respectively, during the period (2005/2006-2009/2010). The table also showed the calculated rates for each of the sessions to be $5.71 \%, 7.08 \%, 5.57 \%, 8.32 \%$ and $6.05 \%$ respectively. A critical look at the data showed a fluctuating movement during the period under review. This was revealed by the calculated rates for each of the sessions studied and the mobility trend can be represented thus; 


$2005 / 2006$
$5.71 \%<7.08 \% \geq 5.57 \% \leq 8.32 \% \geq 6.02 \%$

The observed analysis seems to indicate a fairly steady trend in students' inter-school mobility in the state's secondary schools during the period under study.

\section{Research Question III}

What factors contributed to Students' inter-school Mobility?

Analysis of the data has been presented in Table 5 and arranged in descending order of magnitude.

An inspection of Table 5 shows that examination malpractice is the most dominant of the sixteen reasons why students moved to a particular school. This is not surprising because examination malpractice has become an incurable cancer; call it HIV/AIDS, in Nigeria's educational system. It is wide spread at all levels of education in Nigeria. Factors such as conducive environment in the school being moved into and inadequate infrastructural facilities in the previous institution, come second place. The least factor was the availability of facilities for core-curricular activities such as sports, music e.t.c.

\section{Research question IV}

What are the consequences of students' mobility on the administration of secondary schools?

To answer this research question, sixteen administrative tasks of school heads were identified. The responses were analyzed for the various tasks and the mean scores were arranged in descending order. A four points Likert type scale was used. The highest weighed mean score was " 4 " and the lowest mean score was "1". The midpoint (2.50) was considered as the critical point for determining the acceptance of the item as affecting administrative task. All items with a mean score above 2.50 were considered to have had impact on the administrative tasks under consideration. Table 6 shows the results of the analysis; that inter-school mobility brings about under-population of some schools and over-population of others. It also brought about difficulty in administering continuous assessment, monitoring of students' academic performance, and problems in schools record keeping. It was found that inter-school mobility had no impact on the actual teaching time in a school.

TABLE 5

Reasons for Movement in Descending Order

\begin{tabular}{|c|c|c|c|c|}
\hline REASONS FOR MOVEMENT & $\begin{array}{c}\text { NO OF } \\
\text { SCHOOLS }\end{array}$ & $\begin{array}{r}\text { MEAN } \\
\text { SCORE }\end{array}$ & $\begin{array}{l}\text { STANDARD } \\
\text { DEVIATION }\end{array}$ & $\begin{array}{c}\% \\
\text { PERFORMANCE }\end{array}$ \\
\hline Examination malpractice & 399 & 3.28 & 0.77 & 81.75 \\
\hline Conducive environment & 399 & 3.25 & 0.67 & 81.25 \\
\hline $\begin{array}{l}\text { Inadequate infrastructural facility (in } \\
\text { previous school) }\end{array}$ & 399 & 3.24 & 0.65 & 81.00 \\
\hline $\begin{array}{l}\text { High percentage success in the Sec.Sch. } \\
\text { certificate examination in the new } \\
\text { school moved into. }\end{array}$ & 399 & 3.24 & 0.89 & 81.00 \\
\hline $\begin{array}{l}\text { School with limited number of teaching } \\
\text { staff in previous school. }\end{array}$ & 399 & 3.23 & 0.72 & 80.75 \\
\hline $\begin{array}{l}\text { A school with a clear vision and } \\
\text { mission. }\end{array}$ & 399 & 3.18 & 0.69 & 79.50 \\
\hline $\begin{array}{l}\text { The quest to remain within walking } \\
\text { distance. }\end{array}$ & 399 & 3.11 & 0.81 & 77.75 \\
\hline $\begin{array}{l}\text { Availability of science and } \\
\text { technical/vocational facilities }\end{array}$ & 399 & 3.09 & 0.73 & 77.28 \\
\hline $\begin{array}{l}\text { A school that is noted for good } \\
\text { discipline. }\end{array}$ & 399 & 3.07 & 0.77 & 76.75 \\
\hline $\begin{array}{l}\text { Lack of information or highly } \\
\text { subjective and false information. }\end{array}$ & 399 & 3.07 & 0.74 & 76.75 \\
\hline $\begin{array}{l}\text { Rejection-based discipline (discipline } \\
\text { that is devoid of love) }\end{array}$ & 399 & 3.04 & 0.77 & 76.00 \\
\hline Unfriendly school head & 399 & 3.03 & 0.77 & 75.75 \\
\hline $\begin{array}{l}\text { Negative interaction between parents } \\
\text { and teachers. }\end{array}$ & 399 & 3.02 & 0.62 & 75.50 \\
\hline The need to remain with one's parents. & 399 & 2.98 & 0.71 & 74.50 \\
\hline $\begin{array}{l}\text { The ability of a school to provide a } \\
\text { learner-friendly environment. }\end{array}$ & 399 & 2.97 & 0.77 & 74.25 \\
\hline $\begin{array}{l}\text { Availability of facilities for core- } \\
\text { curricular activities. }\end{array}$ & 399 & 2.87 & 0.80 & 71.75 \\
\hline
\end{tabular}

Minimum significant score $=\geq 2.50$ 


\section{Discussion of Findings}

For the purpose of clarity, the results have been discussed in line with the research questions. The analysis of data indicated the calculated students' inter-school mobility to be $6.54 \%$. This is considered low, when compared with the finding of Ofoegbu (1996) with a rate of $9.78 \%$ and to the study by White and Thomas (1991) who reported $20 \%$ or more rate of inter-school movement and was considered as high. The analysis also showed that enrolment increased during the years under study while inter-school mobility figures were surprisingly fairly steady.

\section{TABLE 6}

Impact of students' Inter-School Mobility on School Administrative Tasks In Descending Order

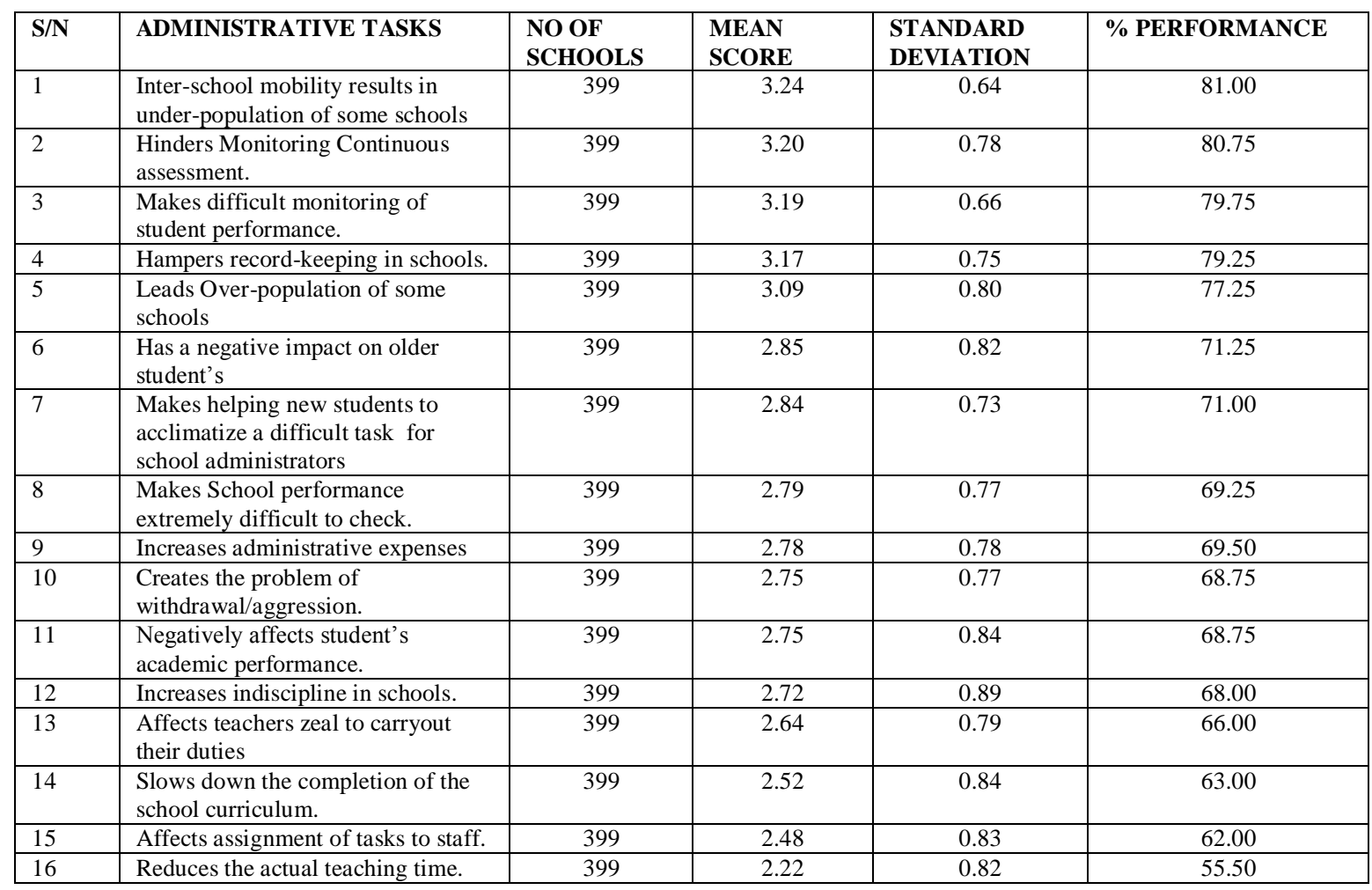

\section{Minimum significant score $=\mathbf{2 . 5}$}

One would have expected that an increase in students' enrolment would have translated into more movement but this was not the case. A possible explanation for this finding could be attributed to the fact that Delta State Secondary Schools, irrespective of type and location, are to a great extent similar in their structure and curriculum offerings.

The result of this study also suggested a fairly steady trend in students' mobility in the state. This is contrary to the researcher's expectation that the result will support the assumption that students' inter-school movement is on the increase. It is also not in consonance with the findings of some studies conducted outside the country, Nigeria, particularly in the United States of America. For example, the findings from the studies by Palmer (1991) and Lee and Burkam (1992) indicated an increased trend. The fairly steady trend of students' inter-school movement in Delta State, though an astonishing finding, was not surprising. The result seem to reflect the progressive fall in the country's battered economy and increase in violence, a situation which discouraged parents from encouraging their wards to change schools, or move from one city to another.

Amongst the factors identified as encouraging inter-school mobility were; the desire to indulge in examination malpractice in order to excel both in internal and external examinations, conducive learning environment, availability of infrastructure for teaching, learning and vocational facilities and good teaching staff. While Ofoegbu (1996) found lack of science and technology facilities as the most contributory factor that influenced students' mobility and Crespar (1996) attributed such movement to students 'dissatisfaction with their current school or the possibilities of greater satisfaction in another school, this finding showed that the number one motivation for such mobility was the desire to engage in examination malpractice. 
The analysis of data on the implications of students' mobility revealed that the act has significant impact on school administrative tasks. When presented in descending order, the researchers observed that all except two of the problem items advanced for the study were significant, since most of the scores were above the indexed mean score of 2.50. These findings of negative consequeses of student mobility corroborated those by Eric Cleaning House (1991), Newman (1988), CRESPAR (1996), Smither \& Clarke (2008), Schwaitz et al (2007) and Education Week (2004). These authors, amongst others, found problems associated with students' interschool mobility to include the following; enormous stress on school in making staffing and calendar decisions, making meaningless attempts to monitor school performance because student population tested one year has largely changed by the next (Newman, 1988, Sewell, 1982). Furthermore, the phenomenon tends to increase review of materials which slows the curricular pace and decreases the opportunity to learn for all students and that the behavioural problems of mobile students also impact on the attitudes of non-mobile students and those of their teachers (CRESPAR, 1996). Other consequeses of student mobility included greater risk for dropping out; socio-psychological problems of becoming acquainted with new rules and regulations in their new school (Rumberger, 2003, Smither \& Clarke, 2008), lower students achievement levels due to discontinuity of curriculum between schools and difficulty of developing new relationships (Education Week, 2004).

The finding of the study also showed that there was an increase in the rate of indiscipline in schools as a result of students' inter-school movement. This is in line with the finding by Cherry (1991). In discussing educational administration in relation to student's mobility, the author argued that movement increases the number of administrative problems such as riots and students needing attention; some children become withdrawn and silent while others become withdrawn and aggressive. Furthermore, the analysis also revealed that students' inter-school mobility affected the morale of teachers. This finding agrees with the study conducted by Lash and KirkPatrick (1994), who reported that, teachers morale suffers when lessons are limited to basic skills. Finally, the analysis showed that students' mobility may not have a significant influence on the assignment or responsibilities to staff and actual teaching time in a school.

The location of a school was found to influence significantly the rate at which students moved from one school to another. From this study, students' inter-school mobility occurred in both rural and urban schools though the urban schools recorded a lower overall mean rate of $6.00 \%$ while the rural schools recorded a higher overall rate of $7.30 \%$. One of the likely reasons for lower rate of students' mobility in the urban secondary schools than in the rural secondary schools in Delta State, could be attributed to rural-urban drift of parents and students' preference for schools with basic amenities which are absent in most rural settings. This finding is in consonance with those found in the study conducted by Onokarhoraye (1977), who indicated that a number of schools located in urban areas enjoy facilities such as good science laboratory, electricity, pipe borne water, good roads, good transport system and postal services. Frank and Hartman (2003), also reported that students' inter-school mobility increases the problem of record keeping and students cumulative files. Frank et al (2003), also found that records are often withheld pending payment of students' fees. Therefore, schools with high mobility rate are at serious administrative disadvantage.

\section{Summary And Conclusion}

The study revealed that several factors were responsible for students inter-school mobility in Delta State of Nigeria and the movement is more from rural to urban schools and that this phenomenon impacted negatively on schools and the several administrative tasks performed by school heads. In the light of these negative impacts, it has been recommended that effective strategies should be formulated and effectively implemented to reduce incidents of students' inter-school movement. These proactive policies and rules would go a long way to guiding parents and students in the latter's movement from one school to another at the same level or at a higher level. For example, there should be a policy that movement into a school is at the beginning of a session. Furthermore, schools should have guidance-counselors who should organize orientation for newly admitted mobile students and teachers should also be provided professional renewal opportunities to enable them acquire skills that would help them to cope with the challenges posed by the in-take of mobile students into their classrooms and/or schools.

\section{Reference:}

[1]. Bubtana, A. (1983). “Academic mobility in Arabs Regions". Journal of the International Association of Universities (I.A.U.),6(3), 19-27.

[2]. Chaika, C.(1999). "Helping students cope with a moving experience; The responsive classroom, retrieved oct.1, 2004 from www.responsiveclassroom.org/newsletter.

[3]. Eric Clearing House on Urban education (1991)." Highly mobile students; education problems and possible solutions", Eric/CUE Digest, 73 .

[4]. Federal Republic of Nigeria (2004). National Policy on Education (2004 Revised). Lagos; NERDC Press

[5]. Frank, T.M, and Hartman, C.(2003). "Student Mobility; how some children get left behind". The Journal of Negro Education, 72(1), 1-5. 
[6]. Frank, T.M., Iskan, J.A. and Parra, M.T.(2003). A pervasive school culture for the betterment of student outcomes: One schools approach to student mobility". The Journal of Negro Education, 7(1):150-156.

[7]. Ofoegbu, Felicia I. (1996). "Students-Interschool Movement (1991-1994) and its implications for secondary school management in Edo State" (Unpublished), Ph.D. Theses in Educational Administration, University Of Benin, Benin City.

[8]. Rumberge, R.W, Larsen, K. W, Ream, R.E. and Palardy, G. J. (1999). The Educational Consequences of mobility for California Students and Schools. Berkeley, C.A. Policy Analysis for California Education ED441 040

[9]. Bilquees, F. \& Saqib, N. (2004). Drop Out Rates and Inter - School Movements: Evidence from panel data Islamabad: Pakistan Institute of Development Economics

[10]. CRESPA Research and Development Report (1996). Urban Student mobility disrupts education and reform efforts" retreved on-line http//scor.cos.jhu.edu/crespar/urbanmobile.htm 21/03/2013.

[11]. Education Week (2004). "Student mobility", www.edweek.org/ew/issues/student-mob, Education Week, August 4, 2004.

[12]. Hnushek, E.A, kain, J.F, \& Rivkin, S.G (2004). "Disruption Veisus tiebout improvement: the costs and benefits of switching schools" Journal of Public Economics, 88 (9):13-18

[13]. Newman, J (1988), What shall we do about the highly mobile student? Mt Veinon, WA: The Research Center, ED 30554.5

[14]. Rumberger, R. W. (2003). "The causes and Consequences of student mobility: Journal of Negro Education, 72(1): 6-21.

[15]. Sechwartz, A.E, Stiefel, L. \& Chalico, L. (2007) The multiple dimensions of student mobility_NYU Stainhardt: Institute for Education \& Social Policy.

[16]. Schuler, D(1990), "Effects of family mobility on Student Achievement: ERS spectrum,_8(4), 19-24 fall.

[17]. Sewell, Carl (1982). The Impact of Pupil Mobility on assessment and its implications for programme planning Brooklyn, NY: Community School District. ED 228322

[18]. Smither, C. \& Clarke, Ben (2008). The Chaos factor: A study of the Student mobility in Indiana Journal of Undegraduale Research, 1-25 